\title{
Potential Activity of the Achillea wilhelmsii Leaves on Bacteria
}

\author{
L. Amjad, M. Mohammadi-Sichani, and M. Mohammadi-Kamalabadi
}

\begin{abstract}
Achillea wilhelmsii is belong to Asteraceae family. This plant is from medicinal plants in Iran customary medicine.The aim of this study was to appraise of effects of the leaves essential oil and methanol extract of the Achillea wilhelmsii on the growth of the bacteries. In this study after collecting and provision plant, leaves essential oil were obtained by hydrodistillation and leaves methanol extract were obtained using a Soxhlet apparatus. The effects of methanol extract antimicrobial were assessed using Agar Well Diffusion method and also using Dilution Test method. The effects of essential oil antimicrobial were determined by using Agar Dilution Assay. Dates were analyzed using Chi-square and AVONA test in the $p$ $<0 / 001$.Leaves methanol extract had more effect against Bacillus cereus and Staphylococcus aureus bacteries and showed weak effect against Escherchia coli and was not abserved any growth inhibition effect against Pseudomonas aeroginosa,also leaves essential oil had inhibition effect against Bacillus cereus, Staphilococcus aureus and Escherchia coli and did not have any inhibition effect against Pseudomonas aeroginosa.Leaves methanol extract and essential oil of Achillea wilhemsii have antibacterial effects,therefore we will be able perform researches with extraction of this plant effective compound for the treatment of infectious diseases.
\end{abstract}

Keywords-Achillea wilhelmsii, antibacterial effect, essential oil, ,methanol extract.

\section{INTRODUCTION}

Use of traditional medicine in Asia a long history of human interactions with the environment. Plants used for traditional medicine contain substances that can be used to treat chronic as well as infectious diseases. A knowledge of how to use the plants against different illnesses may be expected to have accumulated in areas where the use of plants is still of great importance. The medicinal worth of plants lies in some chemical substances that produce a definite physiological action on the human body. The most important of these bioactive compounds of plants are tannins, alkaloids, flavanoids and phenolic compounds [1]. In developing countries, farmers, people of small isolate villages and native communities use folk medicine for the treatment of common infections. The Achillea, which belongs to the family Compositae (Asteraceae) and comprises more than 120

Manuscript received August 16, 2011; revised September 1, 2011.

L. A. is with the Department of Biology, Falavarjan Branch, Islamic Azad University, Esfahan-Iran ( Corresponding auther, telefax: +98-312-312-0136 e-mail: amjad.leila@gmail.com or amjad@iaufala.ac.ir).

M. Ms. is with the Department of Microbiology, Falavarjan Branch, Islamic Azad University, Esfahan-Iran (e-mail: mohammadis_m@ yahoo.com or mohamadi_m@iaufala.ac.ir).

M. Mka. Author is with the Young Researchers Club, Falavarjan Branch, Islamic Azad University, Esfahan-Iran (e-mail: min_mohammady_1365@ yahoo.com). species. These plants are medicinal perennial herbs that are native to Europe and Western Asia, although they are also found in Australia, New Zealand and North America [2]. Several effects, such as anti-inflammatory, antihypertensive, and anti-hyperlipidemia and antitumor have been reported for Achillea. It is widely used in traditional medicine for gastrointestinal disorders and there are some reports of its effects, such as antispasmodic, choleretic, antiulcer, antibacterial (Helicobacter pylori), and hepatoprotective, on the gastrointestinal tract [3]. Achillea wilhelmsii C. Koch (Asteraceae) is widely found in different parts of Iran. This plant is full of flavonoids and sesquiterpene lactones, which have been shown to be effective in lowering blood lipids and hypertension [4], and widely used in Iranian traditional medicine for gastrointestinal disorders. It has chemical components, including flavonoids, alkaloids (achilleine), cineol, borneol, $\alpha$ - and $\beta$-pinen, camphor, caryophyllene, thujene, rutin, sesquiterpenoids, and monoterpenoids [3].

Thus, the main aim of the present project was to carry out a biological investigation on Achillea wilhelmsii C. Koch from the Iran. In this study, Achillea wilhelmsii were collected for evaluation of their antimicrobial activities and were tested against several pathogenic bacteria.

\section{MARERIAL AND METHODS}

Achillea wilhelmsii C. Koch was collected from around area of Isfahan city (Iran) in the May of 2009. The voucher specimen was deposited at the herbarium of Research Institute of Isfahan Forests and Rangelands. The plant materials were dried under shade and ground into fine powder using electric blender, then, $60 \mathrm{~g}$ of leaves powder were extracted with $300 \mathrm{ml}$ methanol $\left(\mathrm{CH}_{3} \mathrm{OH}\right)$ by Soxhlet extraction for 8 hours. The residue was dried over night and then evaporated by using a rotary evaporator and freeze dryer. The dried extracts were stored at $-20^{\circ} \mathrm{C}$ until used. The extracts were dissolved in $5 \%$ aqueous dimethylsulfoxide (DMSO) with and sterilized by filtration through a $0.45 \mu \mathrm{m}$ membrane filter. The essential oils were obtained by hydrodistillation using a Clevenger-type apparatus for $3 \mathrm{~h}$, from leaves of A.wilhelmsii. The oil yields were $80 \mu \mathrm{l}(300 \mathrm{~g}$ leaf powder with $1000 \mathrm{ml}$ water). The essential oils were dissolved in 5\% aqueous dimethylsulfoxide (DMSO) and were dried over anhydrous sodium sulfate overnight and kept in sterile sample tubes in refrigrator. Microorganisms were obtained from the Institute of Scientific and Industrial Researchs, Iran. Two strains of gram-negative bacteria Escherichia coli (ATCC 25922), Pseudomonas aeruginosa (ATCC 27853), and two strains of gram-positive bacteria Bacillus cereus(ATCC 1274) and Staphylococcus aureus 
(ATCC 25923)] were used. The cultures of bacteria were maintained in their appropriate agar slants at $4^{\circ} \mathrm{C}$ throughout the study and used as stock cultures.

For the study of antibacterial activity, total count of isolated strains were standardized to equivalent a 0.5 MacFarland Nephelometer standard $\left(1 \times 10^{8} \mathrm{cfu} / \mathrm{ml}\right)$ by Mueller-Hinton broth and then diluted as 1:10. Antibacterial activity was studied by the agar well diffusion method [5]. Mueller Hinton agar was used as the bacteriological medium. The extracts were diluted in 5\% dimethylsulphoxide (DMSO) at the concentrations of $20 \mathrm{mg} / \mathrm{Ml}, 30 \mathrm{mg} / \mathrm{mL} 50 \mathrm{mg} / \mathrm{mL}$ and $400 \mathrm{mg} / \mathrm{mL}$. The Mueller Hinton agar was melted and cooled to $48-50^{\circ} \mathrm{C}$ and a standardized inoculum $\left(1.5 \times 10^{8} \mathrm{CFU} / \mathrm{mL}\right.$, $0.5 \mathrm{McF}$ arland) was then added aseptically to the molten agar and poured into sterile Petri dishes to give a solid plate. Wells were prepared in the seeded agar plates. The test compound $(100 \mu \mathrm{l})$ was introduced in the well $(6 \mathrm{~mm})$. The plates were incubated overnight at $37^{\circ} \mathrm{C}$. The antimicrobial spectrum of the extract was determined for the bacterial species in terms of zone sizes around each well. The diameters of zone of inhibition produced by the agent were compared with those produced by the commercial control antibiotics, chloramphenicol $(30 \mu \mathrm{l})$. The experiment was performed three times to minimize the error and the mean values are presented.

Minimal inhibitory concentration (MIC) and minimal bactericidal concentration (MBC) were determined for the extracts that showed total growth inhibition using the protocol described above. Extract concentrations of $6 / 25$ to $200 \mathrm{mg} / \mathrm{ml}$ were evaluated. The concentration at which there was no visually detectable bacterial growth was taken as the MIC and the concentration at which there was no bacterial growth after inoculation in Müeller-Hinton agar was taken as the MBC [5]. Means of triplicate measurements and standard errors were determined for each sample.

\section{RESULTS}

Results were analyzed and bacteria growth inhibition were confirmed after inoculation in Müeller-Hinton agar. The extracts showed some degree of inhibition of bacterial growth at different concentrations. The methanol extract of the leaf exhibited antibacterial activity at varied levels against Staphylococcus aureus, Bacillus cereus and Escherichia coli. The methanol extract of Achillea wilhelmsii was least active against Pseudomonas aeruginosa in comparision to all the microorganisms tested. The extract was more active against Gram-negative bacteria as compared to Gram-positive. The inhibitory effect of the extract was compared with standard antibiotic, chloramphenicol.

The antibacterial activity of the methanol extract of the leaves Achillea wilhelmsii were determined against four bacterial strains which is reported in Table 1. The MIC and $\mathrm{MBC}$ of these extracts are currently being obtained and are reported in Table 2 .

The essential oil of the leaf exhibited antibacterial activity at against Staphylococcus aureus, Bacillus cereus and Escherichia coli, but, has not antibacterial activity at against Pseudomonas aeruginosa.
TABLE I: ZONE OF INHIBITION (LEAVE METHANOLIC EXTRACT) FoR

\begin{tabular}{|c|c|c|c|c|c|c|}
\hline \multicolumn{7}{|c|}{ BACTERIA } \\
\hline $\begin{array}{l}\text { Concentrati } \\
\text { on } \\
\text { Bacteria }\end{array}$ & $\begin{array}{l}400 \\
(\mathrm{mg} / \mathrm{ml})\end{array}$ & $\begin{array}{l}\mathbf{5 0} \\
(\mathrm{mg} / \mathrm{ml})\end{array}$ & $\begin{array}{l}30 \\
(\mathrm{mg} / \mathrm{ml})\end{array}$ & $\begin{array}{l}20 \\
(\mathrm{mg} / \mathrm{m} \\
\text { l) }\end{array}$ & $\begin{array}{l}\text { Con } \\
\text { trol } \\
(-)\end{array}$ & $\begin{array}{l}\text { Con } \\
\text { trol } \\
(+)\end{array}$ \\
\hline $\begin{array}{l}\text { Staphilococc } \\
\text { us aureus }\end{array}$ & $\begin{array}{l}18 \pm \\
0.816\end{array}$ & $\begin{array}{l}18 \pm \\
0.816\end{array}$ & $9 \pm 0.816$ & $\begin{array}{l}8 \pm \\
0.816\end{array}$ & 6 & 20 \\
\hline $\begin{array}{l}\text { Bacillus } \\
\text { cereus }\end{array}$ & $\begin{array}{l}21.75 \pm \\
0.5\end{array}$ & 12 & 12 & $\begin{array}{l}9 \pm \\
0.816\end{array}$ & 6 & 18 \\
\hline $\begin{array}{l}\text { Escherchia } \\
\text { coli }\end{array}$ & $9 \pm 0.816$ & 6 & 6 & 6 & 6 & 25 \\
\hline $\begin{array}{l}\text { Pseudomon } \\
\text { as } \\
\text { aeroginosa }\end{array}$ & 6 & 6 & 6 & 6 & 6 & 23 \\
\hline
\end{tabular}

TABLE II: DETERMINATION OF MIC AND MBC FOR BACTERIA

\begin{tabular}{lcc}
\hline Bacteria & $\begin{array}{l}\text { MBC } \\
(\mathbf{m g} / \mathbf{m l})\end{array}$ & $\begin{array}{c}\text { MIC } \\
(\mathbf{m g} / \mathbf{m l})\end{array}$ \\
\hline Staphilococcus aureus & 25 & 12.5 \\
Bacillus cereus & 12.5 & 6.25 \\
Escherchia coli & 200 & 100 \\
Pseudomonas aeroginosa & - & - \\
& & \\
\hline
\end{tabular}

\footnotetext{
MIC: Minimum Inhibitory Concentration

MBC: Minimum Bactericidal

Concentration
}

\section{DISCUSSION}

Plants have an extremely ability to synthesize aromatic products, most of which are phenols [6]. Most are secondary metabolites and in many cases, these products serve as plant defense mechanisms against predation by microorganisms, insects, and so forth. Some, such as terpenoids, give plants their odours, others (quinones and tannins) are responsible for plant pigment. Many compounds are responsible for plant flavor and some of the same herbs and spices used by humans to season food yield useful medicinal compounds [6].

Plant essential oils and extracts have been used in food preservation, pharmaceuticals, alternative medicine and natural therapies [7]. These are potential sources of novel antimicrobial compounds especially against bacterial pathogens. Achillea wilhelmsii is known for many years in the folk medicine. In vitro studies in this work showed that Achillea wilhelmsii leaves inhibited bacterial growth but their effectiveness varied. Totally, the Gram-positive bacteria are more susceptible than Gram-negative bacteria due to the differences in their cell wall structure. Gram-negative organisms are considered to be more resistant due to their outer membrane acting as a barrier to many environmental substances, including antibiotics [8]-[10]. However, the results from this study reveals that the essential oils of Achillea wilhelmsii leaves rich in monoterpenes, including: camphor , 1, 8 - cineole, borneol and myrtenol [11]. This compounds have been reported to display strong antibacterial effects [7], [12]-[13]. Thus, this plant is full of flavonoids and sesquiterpene lactones [4] and leaves methanolic extract have also been shown to possess good anti- bacterial activity. The studies carried out showed that the flavonoids and phenolic compounds have also exhibited notable antimicrobial activity as well [14]-[17]. In general, the essential oil showed better activity than the methanol extract. This observation agrees 
with previous reports by Vukovic et al. (2007) and Sokmen et al. (2004) that methanol extracts showed less activity than essential oil [10],[12].

\section{CONCLUSION}

The results of this study indicate the antimicrobial activity of methanolic extract and essential oil of Achillea wilhelmsii leaves. Our results further support the idea that medicinal plants can be promising sources of potential antimicrobial agents. These results form a good basis for selection of the plant for further phytochemical and pharmacological investigation. However, more studies are needed to investigate the antimicrobial activity of flavonoids and terpens compound kind in this plant and their potential for use in clinical situations.

Studies aimed at the isolation and structure elucidation of antibacterial active constituents from this plant is in progress.

\section{ACKNOWLEDGMENT}

This work was supported by Young Researchers Club that depended on Islamic Azad University, Falavarjan Branch,Iran. The authors also thank Dr. Monajjemi and Ms. Emami from the Department of Biology, Islamic Azad University, Falavarjan Branch for their aid.

\section{REFERENCES}

[1] V. Duraipandiyan, M. Ayyanar and S. Ignacimuthu, "Antimicrobial activity of some ethnomedicinal plants used by Paliyar tribe from Tamil Nadu, India" BMC. Complemen. Altern. Med.,vol. 6, 2007,pp.35.

[2] S. Dokhani, T. Cottrell, J. Khajeddin and G. Mazza, "Analysis of aroma and phenolic components of selected Achillea species," Plan. Food. Hum. Nut., Vol. 6, 2005, pp.55-62.

[3] S. Niazmand, E. Khooshnood and M. Derakhshan, "Effect of Achillea wilhelmsii on rats gastric acid out put at basal, vagotomized and vagal-stimulated conditions," Pharmacog. Mag., vol. 6, 2010, pp.281-285.

[4] S. Asgary, GH. Naderi, N. Sarrafzadegan, N. Mohammadifard, S. Mostafavi and R.Vakili, "Anthypertensive and antihyperlipidemic effect of Achillea wilhelmsii," Drugs. Exp. Clin. Res., vol 26, 2000, pp.89-93.
[5] AAS. AL-Janabi, "Potential activity of the purine compounds caffeine and aminophylline on bacteria," J. Global. Infect. Dis., vol. 3, 2011, pp.133-137.

[6] MM. Cowan, "Plant products as antimicrobial agent," Clinic. Microbiol. Rev., 1999, pp.564- 582.

[7] S. Prabuseenivasan , M. Jayakumar and S. Ignacimuthu, "In vitro antibacterial activity of some plant essential oils," BMC. Complement. Altern. Med., vol. 6, 2006, pp.39.

[8] J. Parekh and S. Chanda, "In vitro antibacterial activity of the crude methanol extract of Woodfordia fruticosa Kurz. flower (Lythraceae)," Braz. J. Microbiol., vol. 38, 2007, pp.204-207.

[9] AJ. Afolayan and AOT. Ashafa, "Chemical composition and antimicrobial activity of the essential oil from Chrysocoma ciliate L. Leaves," J. Med. Plan. Res., vol. 3, 2007, pp.390-394.

[10] N. Vukovic, T. Milosevic, S. Sukdolak and S.Solujic, "Antimicrobial activities of essential oil and methanol extract of Teucrium montanum," Evidence -based. Compl. Alt. Med., vol.4, 2007, pp.17-20.

[11] M. Azadbakht, K. Semnani and N.Khansuri, "The essential oils composition of Achillea wilhelmsii C.Koch leaves and flowers," J. Med. Plan., vol. 2, 2007, pp.55-59.

[12] A. Sokmen, M. Sokmen, D. Daferera, M. Polissiou, F. Candan, M. Unlu and HA. Akpulat, "The in vitro antioxidant and antimicrobial activities of the essential oil and methanol extracts of Achillea biebersteini Afan. (Asteraceae)," Phyto. Res., vol.18, 2004, pp.451-456.

[13] M. Unlu, D. Daferera, E. Donmez, M. Polissiou, B. Tepe and A. Sokmen, " Compositions and the in vitro antimicrobial activites of the essential oils of Achillea Setacea and Achillea teretifolia (Compositae)," J. Ethnopharmacol.,vol.83, 2002, pp.117-121.

[14] SMJ. Yaghoubi, GR. Ghorbani, S. Soleimanianzad and R. Satari," Antimicrobial activity of Iranian propolis and its chemical composition," Daru., Vol.15, 2007, pp.24-48.

[15] R. Mothana, U. Lindequist, R. Geraenert and P. Bednarski, "Studies of the in vitro anticancer,antimicrobial and antioxidant potentials of selected Yemeni medicinial plants from the island Soqotra," BMC. Complement. Altern. Med., Vol.9, 2009, pp.7.

[16] G. Stojanovic, N. Radulovic, T. Hashimoo and R. Palic, "In vitro antimicrobial activity of extracts of four Achillea species:the composition of Achillea clavennae L.(Asteraceae) extract," J. Etnopharmacol., vol.101, 2005, pp.185-190.

[17] AF. Eleyinmi AF, "Chemical composition and antibacterial of Gongronema latifolium," J. Zhejiang. Univ. Sci. B., vol.8, 2007, pp.352-358.

Leila Amjad Received the B.S. in General Biology from Isfahan University, Iran in 1994 and the M.S. degree in Plant Biology, Tehran Tarbiat Moalem University, Iran in1999 and the Ph.D. degree in Plant Biology,Science and Research Branch, Islamic Azad University, Tehran, Iran in 2007. She is a assistant professor, faculty member and head of the biology group, Falavarjan Branch, Islamic Azad University, Esfahan, Iran. Her research interests include plant development, plant proteins and medicinal plants. 